\title{
Aromatic hydrocarbons in sediments of salt marshes and littoral zones from the russian coast of the Barents sea
}

\author{
ANNA KURSHEVA ${ }^{1}$, INNA MORGUNOVA ${ }^{1}$, VERA \\ PETROVA $^{1}$, IVAN LITVINENKO $^{1,2}$, ARINA MALTSEVA ${ }^{2}$ \\ AND ELENA GOLIKOVA ${ }^{2}$
}

${ }^{1}$ FSBI VNIIOkeangeologia

${ }^{2}$ St.Petersburg State University

Presenting Author: A.Kursheva@mail.ru

Qualitative and quantitative determination of aromatic hydrocarbons (ArHCs) in deposits of the Arctic coast is of great importance due to the continuously growing anthropogenic pollution and high vulnerability of intertidal ecosystems.

Polycyclic aromatic HCs (PAHs) are commonly used as indicators of petroleum input to sediments and soils. They include a wide set of natural (pyrogenic, petrogenic and biogenic) and toxic anthropogenic compounds.

Bottom sediments and soils (cores up to $20 \mathrm{~cm}$ ) were collected along the 5 subtidal-intertidal-supratidal transects from salt marshes, muddy sand and rocky littoral zones during the expedition to the Russian part of the Barents Sea (Dalniye Zelentsy, Kola Peninsula) in July 2020 (Fig. 1a; RFBR №18-5420001; NFR \#280724).

The group composition of ArHCs was analyzed using spectrofluorimetry (Panorama-02, Lumex), PAH content and molecular composition using HP5973/HP6850 Agilent Technologies MSD.

The spectral fluorescence profiles of ArHCs indicate the highest input of petroleum products to the supratidal deposits of the salt marsh 4 and sub- and supratidal samples of the littoral zone 5 (Kursheva et al., 2009). The most significant intensity of fluorescence is detected in surface layers of the cores and confirms the fresh input of liquid and solid fuels combustion products.

Total maximum PAH content in sediments from salt marshes reaches $6800 \mathrm{ng} / \mathrm{g}$ dry weight (dw) in supratidal deposits of site 4 (Fig. 1b). The highest value for littoral zones is detected in subtidal sediments of site $5(11500 \mathrm{ng} / \mathrm{g} \mathrm{dw})$.

To assess the damage caused to the ecosystem by the anthropogenic pollution with PAHs we used the toxicity equivalency factor (TEQ, Fig. 1c) and the sediment quality guidelines (SQG, MacDonald et al., 2000) based on two impact assessment criteria: effects range-low and effects range-median (ERL, ERM). Comparative analysis of the TEQ factor shows that it reaches maximum values in sediments of the salt marsh 4 (326 $\mathrm{ng} / \mathrm{g} \mathrm{dw}$ ) and littoral zone $5(710 \mathrm{ng} / \mathrm{g} \mathrm{dw})$. The ERL and EMR criteria assessment indicates that concentrations of the most hazardous PAHs (EPA 2010) exceed limit values and may have toxic effect on sedimentary biota in samples of all littoral zones and supratidal surface of the salt marsh 4 .

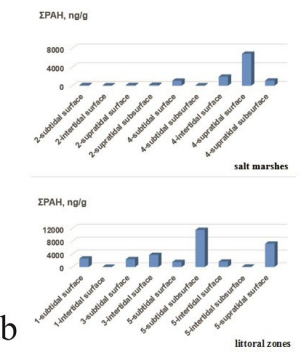

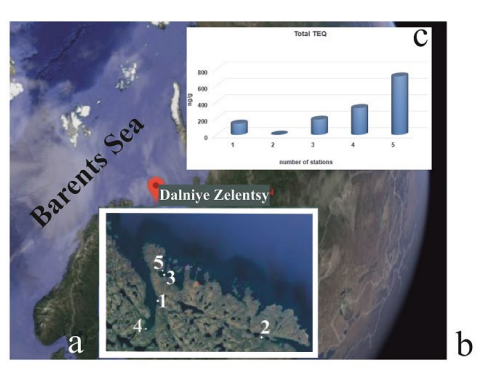

